\title{
Protective Effect of Alcoholic Extract of Garden Cress Seeds on the Histopathological Changes of the Ventral Prostate in Streptozotocin Diabetic Rats
}

\author{
Efecto Protectivo de Extracto Alcohólico de Garden Cress Seeds en los Cambios \\ Histopatológicos de la Próstata Ventral en Ratas Diabéticas por Streptozotocina
}

Mehran Kamani'; Javad Amini Mhabadi²; Mohammad Ali Atlasi'; Fatemeh Seyedi ${ }^{3}$; Emran Kamani ${ }^{4}$ \& Hossein Nikzad $^{2}$

KAMANI, M.; MHABADI, J. A.; ATLASI, M. A.; SEYEDI, F.; KAMANI, E. \& NIKZAD, H. Protective effect of alcoholic extract of garden cress seeds on the histopathological changes of the ventral prostate in streptozotocin diabetic rats. Int. J. Morphol., 35(3):1178-1184, 2017.

SUMMARY: Diabetes mellitus is a common serious metabolic illness occurring worldwide that may lead to male infertility. Various plants have been used in the treatment of diabetes. In this study, the effect of garden cress (Lepidium sativum) seed extract on fasting blood sugar is assessed for its protective effect on histopathological changes in the ventral prostate gland of streptozotocine-induced diabetic rats. Fifty adult male Wistar rats were randomly selected into five groups. Group 1 was the control placebo group where rats received only $0.1 \mathrm{~mL}$ normal saline via gastric gavages. Rats in Group 2 received an intraperitoneal injection of STZ $60 \mathrm{mg} / \mathrm{kg}$ body weight and those with FBS $>250 \mathrm{mg} / \mathrm{dL}$ were considered diabetic. In Group 3, diabetic rats received insulin (3 U/100 g body weight) while in Groups 4 and 5 diabetic rats received $0.1 \mathrm{ml}$ of 200 and $400 \mathrm{mg} / \mathrm{kg}$ respectively of an ethanol extract of Lepidium sativum seeds by gavage daily. The prostate was removed and weighed before transfer to Bouin's solution for histological studies. Administration of the 200 and $400 \mathrm{mg} / \mathrm{kg}$ doses of Lepidium sativum seed extract increased epithelium height and decreased interstitial volume density and fibromuscular thickness of the prostate significantly. Also, the volume density of the epithelium, fibro muscular, lumen, and interstitial tissues were changed significantly. The results suggest that Lepidium sativum seed extract has beneficial effects as a protective agent against the detrimental effects of diabetes on the reproductive system of diabetic male rats.

KEY WORDS: Diabetes; Prostate; Garden cress; Histological parameters.

\section{INTRODUCTION}

Diabetes Mellitus (DM) is a widespread metabolic disorder that has significant adverse effects on vital organs (Kumar et al., 2009). DM also has damaging effects on male sexual function, resulting in impotency, reduced libido, and sterility arising from reduced insulin secretion (Cai et al., 2014). Hyperglycemia in DM-impaired protein function causes histopathological changes in the germinal gonads such as prostate and epididymis (Soudamani et al., 2005a; Agarwal et al., 2006).

The prostate is an accessory genital gland found only in mammals. In rats, the prostatic epithelium consists of two cell types, viz. the Basal and Acinar or Principal cells that are vulnerable to damage in DM (Soudamani et al., 2005a). Over the long term, large amounts of free radicals generated in DM can cause damage to body tissues (Sujatha \& Shalin, 2012).

Insulin plays a key role in the body's metabolism. Accordingly, insulin is one of the most widely used drugs in the treatment of diabetes (Rossetti et al., 1987) in spite of some inherent disadvantages. For example, the drug has a relatively short shelf life and needs to be stored at a low temperature. It cannot be administered orally and fatal hypoglycemia can result from over-dosage. For these reasons, researchers have been trying to find suitable alternatives to insulin using synthetic and plant resources (Hosseyni et al., 2012; Mazloom et al., 2013).

\footnotetext{
${ }^{1}$ Anatomical Sciences Research Center, Kashan University of Medical Sciences, Kashan, Iran.

${ }^{2}$ Gametogenesis Research Center, Kashan University of Medical Sciences, Kashan, Iran.

${ }^{3}$ Faculty of Medicine, Jiroft University of Medical Sciences, Jiroft, Iran.

${ }^{4}$ Student psychology, Arak University, Iran.
} 
Garden cress or GC (Lepidium sativum) that belongs to the family Cruciferae is an annual plant that grows to 30 $\mathrm{cm}$ high. This plant is a rich natural source of flavonoids, coumarins, sulphur glycosides, triterpenes, sterols, and various imidazole alkaloids (Eddouks et al., 2005; Haddad-Kashani et al., 2012; Sharrif-Moghaddasi et al., 2012). There is a lack of information about the effect of GC seed extracts on DM, especially regarding the effect on the ventral lobe of the prostate. Complications of DM have resulted in high medical costs incurred by the Iranian government, and this is among the reasons for our undertaking a study designed to appraise the protective effect of an alcoholic seed extract of GC on histopathological changes of the ventral lobe of the prostate gland of STZ-induced diabetic rats.

\section{MATERIAL AND METHOD}

Induction of Diabetes. After an overnight fasting, rats were injected intraperitoneally (IP) with a single dose of $60 \mathrm{mg} /$ kg body weight of streptozotocine (STZ, Sigma-Aldrich, USA. To prepare the solution, $10 \mathrm{mg}$ of STZ was dissolved in $0.1 \mathrm{~mL}$ of $0.1 \mathrm{M}$ citrate buffer, $\mathrm{PH} 4.5$. Three days after STZ treatment, blood glucose level was measured by an Easy glucometer (Beurer GL40, Hungary). Rats with polyuria and blood sugar levels exceeding $250 \mathrm{mg} / \mathrm{dl}$ were considered diabetic (Soudamani et al., 2005b).

Garden cress (GC) seed extract. GC seeds were obtained from Barij Essence Company in Kashan, Iran. To prepare the alcoholic extract, $500 \mathrm{~g}$ of GC seeds were ground and mixed completely in $96 \%$ ethanol for 24 hours. The mixture was filtered and ethanol was added before standing for another 12 hours and filtered again. The resulting material was dried in a $50{ }^{\circ} \mathrm{C}$ oven. The dried extract was weighed and solutions of 200 and $400 \mathrm{mg} / \mathrm{kg}$ in distilled water were prepared.

Animal experiments. Fifty healthy adult male albino Wistar strain rats (Kashan University of Medical Sciences, Kashan, Iran) 8 weeks old and weighing 280-320 g were maintained in a temperature- controlled room with a $12 \mathrm{~h} / 12 \mathrm{~h}$ light/dark schedule and provided with standard rat pelleted diet and water. The experiments were approved by the university's Animal Research Committee.

Experimental design. Fifty rats were randomly categorized into five groups of ten animals. Group 1 comprised healthy animals that received $0.1 \mathrm{~mL}$ of saline by stomach gavage to reflect the effect of gavage on the animals. Group 2 consisted of diabetic rats that received no further treatment. In Group 3 , diabetic rats received daily subcutaneous injections insulin (Sigma-Aldrich, USA), once in the morning (10 a.m., $2 \mathrm{U}$ ) and again in the afternoon (4p.m., 4 U) (Soudamani et al., 2005b; Pinheiro et al., 2011). Groups 4 and 5 comprised diabetic rats that received respectively 200 and $400 \mathrm{mg} / \mathrm{kg}$ of GC seed extract by stomach gavage for 28 days.

Tissue sample collection and processing. Four weeks and $24 \mathrm{~h}$ after the last dose of treatment, the animals were weighed and anesthetized with chloroform. Blood samples were collected from the heart ventricle for the measurement of the fasting blood sugar (FBS) level. The ventral lobe of the prostate gland was carefully dissected out, cleaned of adhering fats and connective tissues, and weighed. Samples were fixed in Bouin's fluid for histological examination. The tissue samples were then processed (Shandon Eliot model) to prepare paraffin blocks. Histological sections ( $5 \mathrm{~mm}$ ) were stained with Hematoxylin and Eosin (H\&E) (Mohamadi et al., 2014).

\section{Histological examination}

Morphometric studies. Microscope sections of the ventral lobe of the prostate were examined under an inverted microscope (Nikon Inverted Microscope Eclipse Ti with DS camera control Unit Ds-L2) equipped with a square lattice containing 121 intersections to determine volume density (Weibel \& Paumgartner, 1978). For each animal, morphometric studies were performed on five sections (Mahabadi et al., 2013; Mahabadi et al., 2016).

Prostate tubules and lumen. The mean diameter of the tubule and lumen of the prostate was determined in 5 random tubules using an oculometer. The mean diameter of the tubule was measured as: Mean tubule diameter $=($ length + breadth of the tubule) / 2). The mean diameter of the lumen was measured as: Mean lumen diameter $=$ mean diameter of tubule $-(2 \mathrm{x}$ diameter of epithelium).

The epithelium height and fibromuscular thickness of the tubules were determined by a Nikon microscope.

Volume density ( $\mathrm{Vv})$. The point-counting method was used to measure the volume density of the whole tubule, lumen, epithelium, and interstitial tissue. The volume density was obtained by dividing the number of points on a tissue compartment (PN) by the total number of points (Ptn). Volume density was determined in X100 with the following formula (Romppanen et al., 1980).

$$
\mathrm{Vv}=\mathrm{PN} / \mathrm{ptn}
$$

Statistical analysis. Statistical analyses were carried out by ANOVA and post hoc test such as Tukey's HS and Dunnett's T3 test using SPSS 12 software. A P-value of $p \leq 0.05$ was considered as significant. 


\section{RESULTS}

Body and prostate gland weight. Table I compares the effects of STZ-induced diabetes, GC seed extract treatment, and insulin replacement on body and prostate weight. The results showed that induction of diabetes with STZ significantly reduced the body and prostate weight, whereas the administration of $200 \mathrm{mg} / \mathrm{kg} \mathrm{GC}$ seed extract preserved the weight of the prostate partially.

Fasting Blood Sugar (FBS). In diabetic rats, FBS level was significantly increased but administration of $200 \mathrm{mg} / \mathrm{kg} \mathrm{GC}$ seed extract decreased FBS significantly. Table 1 shows the changes of FBS in the different treatment groups.

Histopathological findings. Histopathological changes that were observed included a decrease in prostate epithelium height, density of epithelium, and increase in fibromuscular thickness and density of interstitial in STZ-diabetic rats (Fig. 1).
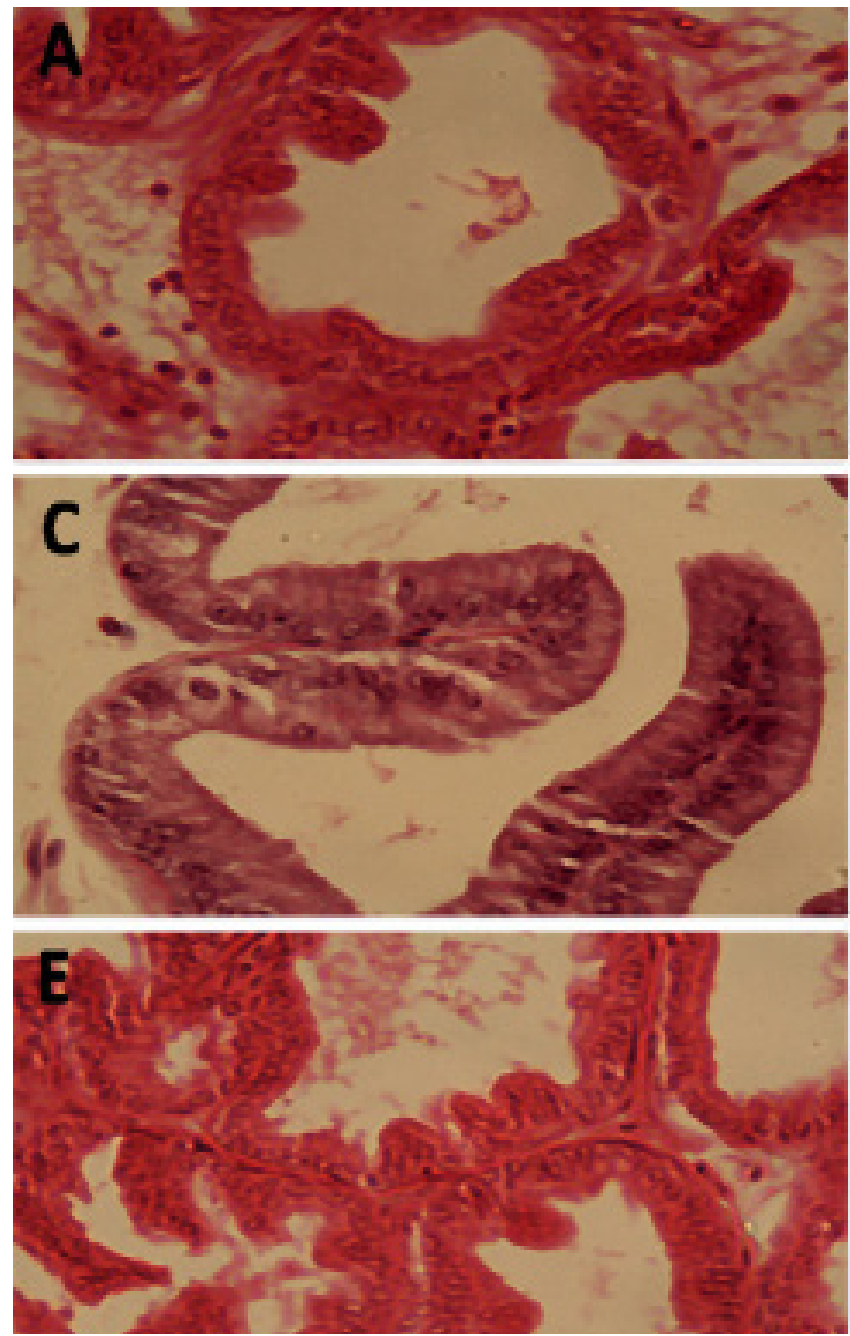

Table II shows the mean values for the epithelium, fibromuscular layer thickness, diameter of the tubule and lumen, and volume density of epithelium, fibromuscular, lumen and interstitial tissues in the ventral lobe of the prostate. In the STZ-diabetes group, epithelium thickness significantly decreased while fibromuscular layer thickness significantly increased.

However, these changes were significantly reduced in the GC-treated groups. In the GC 200 and $400 \mathrm{mg} / \mathrm{kg}$ groups in comparison with the STZ-treated group, not only did epithelium height increase significantly, but there was also significant decrease in fibromuscular thickness. Other changes in histopathological parameters are shown in Table II.
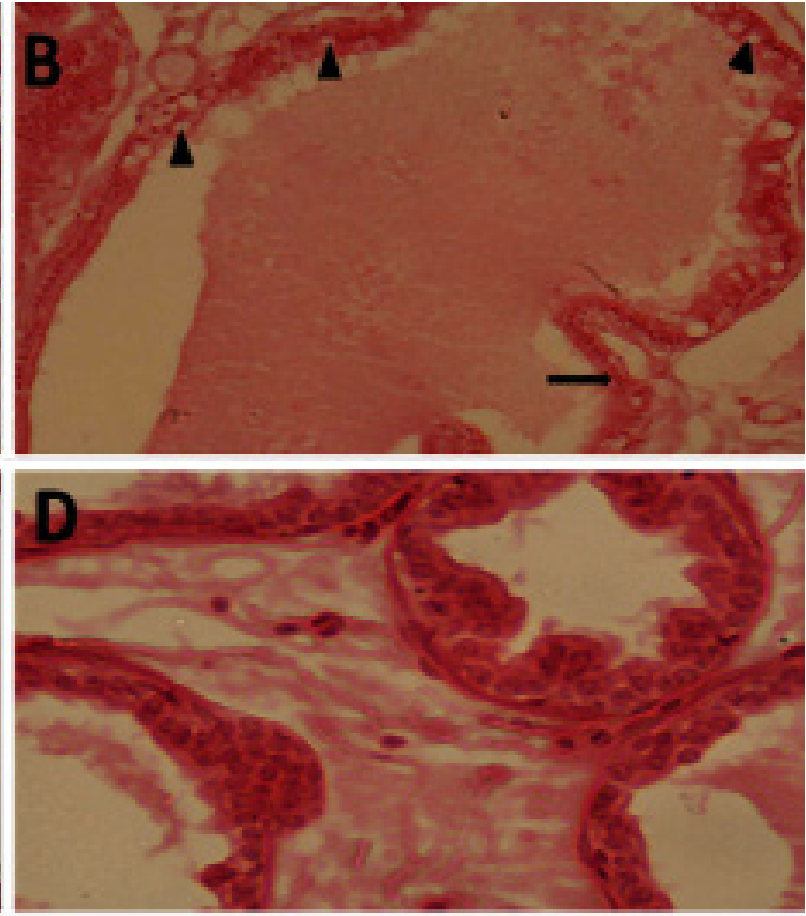

Fig. 1. Protective effect of GC-Treated on histology of ventral prostate in STZ diabetic rats (A) Shows the ephitelium and luminal contents of control groups (B) Shows adverse effect of STZ treatment on prostate tissue such as increase of interstitial, fibromuscular, vacuolization $(\Delta)$ and separation of tissue $(\rightarrow$ ) in diabetic rats. (C) Demonstrates effect of insulin-treated on prostate, in insulin- treated group we can see recovery of prostate epithelium (D) and (E) shows the recovery of prostate by administration of GC seeds extract in 200 and $400 \mathrm{mg} / \mathrm{kg}$. Sections were prepared and stained with $\mathrm{H} \& \mathrm{E}$ and observed with $\mathrm{x} 400$ magnification. 
Table I Protective effect of GC seed extract on histological parameters of ventral prostate in the adult diabetic male rats with

\begin{tabular}{|c|c|c|c|c|c|}
\hline SRazameters & Control & Diabetic & Insulin & $\begin{array}{l}\text { GC } 200 \\
(\mathrm{mg} / \mathrm{kg})\end{array}$ & $\begin{array}{l}\text { GC 400 } \\
(\mathrm{mg} / \mathrm{kg})\end{array}$ \\
\hline Epithelium height $(\mu \mathrm{m})$ & $6.75 \pm 0.96$ & $2.37 \pm 1$ & $5.53 \pm 1.12^{\mathrm{a}^{\prime} \mathrm{b}}$ & $5.64 \pm 0.76^{\mathrm{a}^{\mathrm{b}} \mathrm{b}}$ & $4.45 \pm 1.13^{\mathrm{a}^{\mathrm{b}} \mathrm{b}}$ \\
\hline Fibromuscular thickness $(\mu \mathrm{m})$ & $1.10 \pm 0.30$ & $2.32 \pm 0.59$ & $1.37 \pm 0.41^{\mathrm{b}}$ & $1.37 \pm 0.55^{\mathrm{b}}$ & $1.28 \pm 0.37^{b}$ \\
\hline Diameter of tubule $(\mu \mathrm{m})$ & $50.71 \pm 9.75$ & $53.87 \pm 12.6$ & $47.60 \pm 9.12^{\mathrm{b}}$ & $47.65 \pm 9.18^{b}$ & $46.26 \pm 11.75^{b}$ \\
\hline Diameter of lumen $(\mu \mathrm{m})$ & $37.20 \pm 9.91$ & $49.08 \pm 13.1$ & $36.75 \pm 9.23^{\mathrm{b}}$ & $36.42 \pm 9.41^{\mathrm{b}}$ & $37.36 \pm 11.70^{b}$ \\
\hline Volume density of epithelium (\%) & $40.29 \pm 5.2$ & $22.9 \pm 6.2$ & $36.08 \pm 6.5^{\mathrm{b}}$ & $35.71 \pm 8.3^{\mathrm{b}}$ & $29.96 \pm 8.17^{\mathrm{a}^{\mathrm{b}} \mathrm{b}}$ \\
\hline Volume density of Fibromuscular (\%) & $1.2 \pm 0.9$ & $5.7 \pm 2.7$ & $2.2 \pm 1.7^{\mathrm{a} \mathrm{a} b}$ & $1.8 \pm 1.3^{\mathrm{a} \mathrm{b}}$ & $2.41 \pm 1.65^{\mathrm{a}^{\mathrm{b}} \mathrm{b}}$ \\
\hline Volume density of lumen (\%) & $49.2 \pm 7.4$ & $47.59 \pm 7.92$ & $44.53 \pm 10.3^{\mathrm{a} b \mathrm{~b}}$ & $51.14 \pm 10.5$ & $51.63 \pm 9.18$ \\
\hline Volume density of interstitial (\%) & $9.8 \pm 4.8$ & $23.59 \pm 7.36$ & $16.82 \pm 5.9^{\mathrm{a} b \mathrm{~b}}$ & $11.02 \pm 6.5^{\mathrm{b}}$ & $16 \pm 7.1^{\mathrm{a}^{\mathrm{a}} \mathrm{b}}$ \\
\hline
\end{tabular}

Values are expressed as mean \pm SD for ten rats in each group.

a: Significant differences as compared with the Control group at $\mathrm{P} \leq 0.05$

b: Significant differences as compared with the STZ- diabetic group at $\mathrm{P} \leq 0.05$

Table II Protective effect of GC seed extract on body and prostate weights and FBS in the STZ- diabetes male rats

\begin{tabular}{lccccc}
\hline Parameters & Control & Diabetic & Insulin & GC 200 mgkg & GC400 mgkg \\
\hline Body weight (gr) & $280 \pm 19.4$ & $181 \pm 18.33$ & $272 \pm 15.41^{\mathrm{b}}$ & $190 \pm 21.3$ & $188 \pm 15.8$ \\
Prostate gland weight(gr) & $0.634 \pm 0.1$ & $0.225 \pm 0.03$ & $0.413 \pm 0.05^{\mathrm{a}^{\mathrm{b}} \mathrm{b}}$ & $0.312 \pm 0.09^{\mathrm{a}^{\mathrm{a}} \mathrm{b}}$ & $0.246 \pm 0.06^{\mathrm{a}}$ \\
FBS $_{1}-\mathrm{FBS}_{2}$ & $0.87 \pm 9$ & $1.3 \pm 57$ & $-126 \pm 112^{\mathrm{a}^{\mathrm{a}} \mathrm{b}}$ & $-31.3 \pm 73.8^{\mathrm{a}^{\mathrm{b}} \mathrm{b}}$ & $-1.62 \pm 181$ \\
\hline
\end{tabular}

Values are expressed as mean \pm SD for ten rats in each group.

a: Significant differences as compared with the Control group at $\mathrm{P} \leq 0.05$

b: Significant differences as compared with the STZ-diabetic group at $\mathrm{P} \leq 0.05$

\section{DISCUSSION}

To the best of our knowledge, this is the first study investigating the protective effects of GC seed extract against the STZ-induced side effects of the prostate (a simulation of the diabetic condition) in the rat model. The purpose of the study was to examine the effect of GC seed extract applied at 200 and $400 \mathrm{mgkg}$ on histopathological changes of the prostate and blood glucose in STZ-induced diabetic rats. A comparison was also made with the application of insulin in diabetic rats.

Our study demonstrated that stomach gavage of GC seed extract $200 \mathrm{mg} / \mathrm{kg}$ to diabetic rat reduced blood glucose significantly and increased various histology parameters, particularly the diameter of the prostate epithelium. The increase in the epithelium might be due to high amounts of antioxidant of GC such as flavonoids, coumarins, sulphur glycosides, triterpenes, sterols and various imidazole alkaloids (Eddouks et al.) and vitamins B, C, D and E that are present in the seed extract (Schultz \& Gmelin, 1952).

Several previous studies have reported the positive effect of antioxidants on the reproductive system. Al-Sa' aidi et al. (2009) demonstrated that antioxidants in alcoholic extract of Nigella sativa, such as vitamins A, B and C could increase fertility in male rats. MA Shalaby \& Mouneir (2010) reported antioxidants available in Zingiber officinale root and Cinnamon zeynalicum bark could increase parameters of sperm such as sperm motility, sperm count and viability in alloxan-diabetes rats (Shalaby \& Mouneir). Saber A. Sakr \& Nooh (2013) who studied the effect of Ocimum basilicum extract on cadmium-induced diabetes detected an improvement in testes tissue such as mean tubular diameter and germ cell height that attributed to the antioxidant properties of the plant (Sakr \& Nooh). Aghaei et al. (2014) demonstrated the effect of pumpkin seed extract in cyclophosphamide-treated rats. Vacuolization, disorganization, and separation of epididymal epithelium improved remarkably following the administration of the extract. These changes that were attributed to the presence of antioxidants such as vitamin C, vitamin $\mathrm{E}$ and vitamin $\mathrm{A}$ in pumpkin seed (Aghaei et al.) are in agreement with the findings in our study that antioxidants in GC play major roles in protecting prostate gland tissues from histopathological damage.

GC at $200 \mathrm{mgkg}$ significantly maintained the histoarchitecture of the ventral prostate in STZ-treated rats. The higher dose of $400 \mathrm{mg} / \mathrm{kg}$ achieved this effect partially. Our results are also in agreement with those of Naji \& Shumran (2013). In a study on the testicular and epididymal tissues of rabbits, they showed that consumption of an alcoholic extract of GC seeds at $96 \mathrm{mgkg}$ significantly raised the concentration of sperm and induced other histological changes on the testes and epididymis. These effects were believed to be related to vitamin E found in in GC seeds (Naji \& Shumran). Shukia et al. (2000) reported that alcohol-soluble compound, Allicine, in GC seed extract caused a significant increase in 
blood insulin levels and liver glycogen in diabetic rats treated with alloxan (Shukia et al.). These studies suggested that antioxidants present in GC such as Vitamin E and Allicine are responsible for the maintenance of histoarchitecture of the ventral prostate in GC-treated rats.

Reactive oxygen species (ROS) produced in mitochondria are considered as by-products of normal oxidative metabolism that become altered in DM (Raha \& Robinson, 2001). Khaki et al. (2012) studied the effects of onion (Allium cepa) and ginger (Zingiber officinale) on the sexual behavior of rats after treatment with an antiepileptic drug (lamotrigine). They observed that Vitamins C, E, and B were useful in reducing the toxic effects of free radicals on genital gonads (Khaki et al.).

Our results showed a decrease in blood glucose level after administration of GC seed. We believe the effect could be due to presence of alkaloids, flavonoids, cysteine and glycine. In another study by Amawi \& Aljamal (2012), administration of $20 \mathrm{mg} / \mathrm{kg}$ GC seed extract significantly decreased blood sugar (by $30 \%$ ), cholesterol (by $22 \%$ ), triglycerides (by $25 \%$ ) and LDL (by $23 \%$ ) in diabetic rats due to the antioxidant compounds in GC seeds (Amawi \& Aljamal). Potential nephron-curative, nephron-protective and in vivo antioxidant potential of GC at $200 \mathrm{mg} / \mathrm{kg}$ and $400 \mathrm{mg} / \mathrm{kg}$ against Cisplain that induced nephrotoxicity was shown by Yadav et al. (2010). Antioxidants of GC such as alkaloids, flavonoids, cysteine and glycine have blood glucose-reducing properties as that shown in our study.

Consumption GC seed extract at $200 \mathrm{mg} / \mathrm{kg}$ increased the weight of prostate gland. This could be explained by the fact that seeds of GC have disulfide compounds that are similar to Insulin, which is also a disulfide compound (Tocmo et al., 2015). One interesting finding in the present study was that the consumption of GC at $400 \mathrm{mg} / \mathrm{kg}$ decreased the weight of the prostate while body weight was increased. Similarly, hyper doses of GC have a reverse effect on genital gonads as described by Meikle et al.(1996). In another example, high doses of oleic acid inhibited cholesterol esterase that is essential for the synthesis of testosterone in the Leydig cells. The concentration of cholesterol in the Leydig cells and cholesterol esterase activity in the cytosol and mitochondria were also reduced. There is a good possibility that the use of essential fatty acids in high concentrations can have the reverse effect on the gonads (Meikle et al.).

Insulin treatment of diabetic rats significantly raised the body and prostate weight and gave rise to histology effects such as an increase in the epithelium diameter and the volume density of epithelium. These findings are consistent with those from the study of Bahey et al. (2014) where the histoarchitecture of the prostate anterior lobe was restored, with the epithelium height increased and the mast cell count raised in diabetic rats following insulin treatment. Wagner $e t$ al. (2010) demonstrated that a combination of insulin and steroid hormones partially revived hormonal and angiogenenic imbalance created by DM (Fávaro \& Cagnon, 2010). Sergio et al. (2014) studied the effect of insulin on the function and secretion of the prostate of fetuses in maternal diabetic rats. Their finding showed that insulin applied to maternal diabetic rats restored prostate histology and secretion (Santos et al., 2014). Partial maintenance of serum androgens such as testosterone, estradiol, and prolactin in insulin treated rats might be responsible for the maintenance of the histoarchitecture of the ventral prostate as reported by Sudha et al. (1999).

In the present study, our results showed that DM in rats showed a decrease in body and prostate weight. Increased blood glucose in diabetic rats gave rise to vacuoles and shrinkage in the basal membrane. Our results are also in agreement with those of Kamani et al. (2016) that demonstrated vacuoles and separation of epididymis epithelium in streptozotocin-diabetic rats. Soudamani et al. (2005a) who reported that experimental diabetes had adverse effects on the differentiation of the ventral prostate during sexual maturation of rats. They showed shrinkage of the epithelium in the prostate that arise from DM (Soudamani et al., 2005a). ROS and antioxidants are in balance in the healthy body. In an oxidative disorder such as DM, however, this balance is disrupted, resulting in increased ROS production that causes cell damage and oxidative stress (Agarwal et al., 2008). Several toxic effects of DM on the epididymis and testes related to oxidative stress and radical production that are in agreement to our findings are reported here (Navarro-Casado et al., 2010).

Our finding showed that consumption of 200 and $400 \mathrm{mg} / \mathrm{kg}$ GC could protect the prostate from various side-effects of DM such as vacuolization, shrinkage and separation of epithelium. Our results are in agreement with the findings of Thnaian Althnaian (2014) who examined the effect of a dietary supplementation of GC seeds on liver histopathology in rats fed on a high cholesterol diet. They showed that the administration of $6 \mathrm{~g} / \mathrm{kg} \mathrm{GC}$ seeds restored histopathology of the liver in aspects such as vacuolization, fatty changes, fatty cyst and lobular disarray (Althnaian). In our study, administration of GC seed extract (200 and $400 \mathrm{mg} / \mathrm{kg}$ ) to diabetic rats provided protection against adverse histological parameters of the prostate. Antioxidant compounds in GC seeds could be responsible for this effect. Additional studies involving biochemical factors such as HbA1c, total antioxidant capacity (TAC) and reactive oxygen species (ROS) could throw further light on the beneficial effects of GC seed extracts in the treatment of DM. 


\section{CONCLUSION}

Administration of GC seed extract protected rats from STZ-induced side effects observable in prostate histology. These effects might have occurred through the prevention of oxidative stress. Pending clinical trials that should be undertaken in the future, GC seed extract as a supplementation to insulin treatment might similarly provide a protective effect in DM. While our results indicated an antidiabetic effect of GC, the dosage of the herbal medicine was shown to be an important factor since the beneficial effects could be lost due to over-dosage.

KAMANI, M.; MHABADI, J.A.; ATLASI, M.A.; SEYEDI, F.; KAMANI,E.\& NIKZAD, H. Efecto protectivo de extracto alcohólico de garden cress seeds en los cambios histopatológicos de la próstata ventral en ratas diabéticas por streptozotocina. Int. J. Morphol., 35(3)1178-1184, 2017.

RESUMEN: La diabetes mellitus es una enfermedad metabólica común y grave que ocurre en todo el mundo y que puede conducir a la infertilidad masculina. Se han utilizado varias plantas en el tratamiento de la diabetes. En este estudio se evalúa el efecto del extracto de semilla de Lepidium sativum sobre los niveles de azúcar en sangre, en ayunas, por su efecto protector sobre los cambios histopatológicos en la próstata ventral, de ratas diabéticas inducidas por estreptozotocina (STZ). Cincuenta ratas Wistar adultas fueron divididas aleatoriamente en cinco grupos. El grupo 1 fue el grupo placebo, de control, en el que las ratas recibieron sólo $0,1 \mathrm{ml}$ de solución salina normal mediante sondas gástricas. Las ratas del grupo 2 recibieron una inyección intraperitoneal de $60 \mathrm{mg}$ / $\mathrm{kg}$ de peso corporal de STZ y aquellas con FBS> $250 \mathrm{mg} / \mathrm{dl}$ se consideraron diabéticas. En el grupo 3, las ratas diabéticas recibieron insulina (3 U / 100 $\mathrm{g}$ de peso corporal) mientras que en los grupos 4 y 5 las ratas diabéticas recibieron $0,1 \mathrm{ml}$ de 200 y $400 \mathrm{mg} / \mathrm{kg}$ respectivamente de un extracto etanólico de semillas de Lepidium sativum por gavage diariamente. La próstata se retiró y se pesó antes de transferir a una solución de Bouin para realizar estudios histológicos. La administración de las dosis de 200 y 400 mg / kg de extracto de semilla de Lepidium sativum aumentó la altura del epitelio y disminuyó la densidad volumétrica intersticial y el espesor fibromuscular de la próstata, significativamente. Además, la densidad volumétrica del epitelio fibromuscular, del lumen y el intersticio de los tejidos sufrieron modificaciones significativas. Los resultados sugieren que el extracto de semilla de Lepidium sativum posee efectos beneficiosos como agente protector contra los efectos perjudiciales de la diabetes en el sistema reproductivo de las ratas macho diabéticas.

PALABRAS CLAVE: Diabetes; Próstata; Berro de jardín; Parámetros histológicos.

\section{REFERENCES}

Agarwal, A.; Gupta, S. \& Sikka, S. The role of free radicals and antioxidants in reproduction. Curr. Opin. Obstet. Gynecol., 18(3):325-32, 2006.

Agarwal, A.; Makker, K. \& Sharma, R. Clinical relevance of oxidative stress in male factor infertility: an update. Am. J. Reprod. Immunol., 59(1):2-11, 2008

Aghaei, S.; Nikzad, H.; Taghizadeh, M.; Tameh, A. A.; Taherian, A. \& Moravveji,A. Protective effect of pumpkin seed extract on sperm characteristics, biochemical parameters and epididymal histology in adult male rats treated with cyclophosphamide. Andrologia, 46(8):927-35, 2014.

Al-Sa'aidi, J. A. A.; Al-Khuzai, A. L. D. \& Al-Zobaydi, N. F. H. Effect of alcoholic extract of Nigella sativa on fertility in male rats. Iraqi J. Vet. Sci., 23 Suppl. 2:123-8, 2009.

Althnaian, T. Influence of dietary supplementation of Garden cress (Lepidium sativum L.) on liver histopathology and serum biochemistry in rats fed high cholesterol diet. J.Adv. Vet.Anim.Res., 1(4):216-23, 2014.

Amawi, K. \& Aljamal, A. Effect of Lepidium sativum on lipid profiles and blood glucose in rats. J. Phys. Pharm. Adv., 2(8):277-81, 2012.

Bahey, N. G.; Soliman, G. M.; El-Deeb, T. A. \& El-Drieny, E. A. Influence of insulin and testosterone on diabetic rat ventral prostate: Histological, morphometric and immunohistochemical study. J.Microsc. Ultrastruct., 2(3):151-60, 2014.

Cai, X.; Tian, Y.; Wu, T.; Cao, C. X.; Li, H. \& Wang, K. J. Metabolic effects of testosterone replacement therapy on hypogonadal men with type 2 diabetes mellitus: a systematic review and meta-analysis of randomized controlled trials. Asian J. Androl., 16(1):146-52, 2014.

Eddouks, M.; Maghrani, M.; Zeggwagh, N. A. \& Michel, J. B. Study of the hypoglycaemic activity of Lepidium sativum L. aqueous extract in normal and diabetic rats. J. Ethnopharmacol., 97(2):391-5, 2005.

Fávaro, W. J. \& Cagnon, V. H. Effect of combined hormonal and insulin therapy on the steroid hormone receptors and growth factors signalling in diabetic mice prostate. Int. J. Exp. Pathol., 91(6):537-45, 2010.

Haddad-Kashani, H.; Seyed-Hosseini, E.; Nikzad, H. \& Aarabi, M. H. Pharmacological properties of medicinal herbs by focus on secondary metabolites. Life Sci. J., 9(1):509-20, 2012.

Hosseyni, E. S.; Kashani, H. H.; Asadi, M. H. \& Hosseyni, S. Mode of action of medicinal plants on diabetic disorders. Life Sci. J., 4(9):2776-83, 2012.

Khaki, A.; Farnam, A.; Badie, A. D. \& Nikniaz, H. Treatment Effects of Onion (Allium cepa) and Ginger (Zingiber officinale) on Sexual Behavior of Rat after Inducing an Antiepileptic Drug (lamotrigine). Balkan Med.J., 29(3):236-42, 2012.

Kumar, B. D.; Mitra, A. \& Manjunatha, M. In vitro and in vivo studies of antidiabetic Indian medicinal plants: A review. J. Herb. Med. Toxicol., 3(2):9-14, 2009.

Mahabadi, J. A.; Bafrani, H. H. \& Nikzad, H. Effect of sesame-supplemented diet on prostate and seminal vesicle histology of adult rat. Int. J. Morphol., 34(2):604-9, 2016.

Mahabadi, J. A.; Hassani Bafrani, H.; Nikzad, H.; Taherian, A. \& Salehi, M. Effect of diet contains sesame seed on adult Wistar rat testis. Int. J. Morphol., 31(1):197-202, 2013.

Mazloom, Z.; Yousefinejad, A. \& Dabbaghmanesh, M. H. Effect of probiotics on lipid profile, glycemic control, insulin action, oxidative stress, and inflammatory markers in patients with type 2 diabetes: a clinical trial. Iran. J. Med. Sci., 38(1):38-43, 2013.

Meikle,A. W.; Cardoso de Sousa, J. C.; Hanzalova, J. \& Murray, D. K. Oleic acid inhibits cholesteryl esterase and cholesterol utilization for testosterone synthesis in mouse Leydig cells. Metabolism, 45(3):293-9, 1996

Mohamadi, F.; Nikzad, H.; Taherian, A.; Taghizadeh, M.; Azami-Tameh, A.; Naderian, H. \& Atlasi, M. A. Combined effect of ginger and pumpkin seed extracts on rat testis and serum biochemical parameters after cyclophosphamide treatment. Anat. Sci., 11(1):33-40, 2014.

Naji, N. S. \& Shumran, F. M. The effects of tocopherol extraction from le- 
pidium sativum seeds on the histology of testis, epididymis, and seminal vesicles of adult male rabbits. J.Biol.Agric. Healthc., 3(6):97-100, 2013.

Navarro-Casado, L.; Juncos-Tobarra, M. A.; Cháfer-Rudilla, M.; de Onzoño, L. Í.; Blázquez-Cabrera, J. A. \& Miralles-García, J. M. Effect of experimental diabetes and STZ on male fertility capacity. Study in rats. J. Androl., 31(6):584-92, 2010.

Pinheiro, L. S.; de Melo, A. D.; Andreazzi, A. E.; de Caires Junior, L. C.; Costa, M. \& Garcia, R. M. G. Protocol of insulin therapy for streptozotocin-diabetic rats based on a study of food ingestion and glycemic variation. Scand. J. Lab. Anim. Sci., 38(2):117-27, 2011.

Raha, S. \& Robinson, B. H. Mitochondria, oxygen free radicals, and apoptosis. Am. J. Med. Genet., 106(1):62-70, 2001.

Romppanen, T.; Huttunen, E. \& Helminen, H. J. An improved light microscopical histoquantitative method for the stereological analysis of the rat ventral prostate lobe. Invest. Urol., 18(1):59-65, 1980.

Rossetti, L.; Smith, D.; Shulman, G. I.; Papachristou, D. \& DeFronzo, R.A Correction of hyperglycemia with phlorizin normalizes tissue sensitivity to insulin in diabetic rats. J. Clin. Invest., 79(5):1510-5, 1987.

Sakr, S. A. \& Nooh, H. Z. Effect of Ocimum basilicum extract on cadmium-induced testicular histomorphometric and immunohistochemical alterations in albino rats. Anat. Cell Biol., 46(2):122-30, 2013.

Santos, S. A.; Rinaldi, J. C.; Martins, A. E.; Camargo, A. C.; Leonelli, C.; Delella, F. K.; Felisbino, S. L. \& Justulin, L. A. Jr. Impact of gestational diabetes and lactational insulin replacement on structure and secretory function of offspring rat ventral prostate. Gen. Comp. Endocrinol., 206:60-71, 2014.

Schultz, O.E. \& Gmelin, R. Purification of glycoside from Lepidum sativum by chromatography on a cellulose powder column. Arzneimittelforschung, 2(12):568-9, 1952 .

Shalaby, M. A. \& Mouneir, S. M. Effect of Zingiber officinale roots and Cinnamon zeylanicum bark on fertility of male diabetic rats. Glob. Vet., 5(6):341-7, 2010.

Sharrif-Moghaddasi, M.; Haddad-Kashani, H. \& Azarbad, Z. Capparis spinosa L. Propagation and medicinal uses. Life Sci. J., 9(4):684-6, 2012.

Shukia, R.; Sharma, S. B.; Puri, D.; Prabhu, K. M. \& Murthy, P. S. Medicinal plants for treatment of diabetes mellitus. Indian J. Clin. Biochem., 15(Suppl. 1):169-77, 2000.

Soudamani, S.; Malini, T. \& Balasubramanian, K. Effects of streptozotocin-diabetes and insulin replacement on the epididymis of prepubertal rats: histological and histomorphometric studies. Endocr. Res., 31(2):81-98, 2005.

Soudamani, S.; Yuvaraj, S.; Malini, T. \& Balasubramanian, K. Experimental diabetes has adverse effects on the differentiation of ventral prostate during sexual maturation of rats. Anat. Rec. A Discov. Mol. Cell. Evol. Biol., 287(2):1281-9, 2005

Sudha, S.; Sankar, B. R.; Valli, G.; Govindarajulu, P. \& Balasubramanian, K. Streptozotocin-diabetes impairs prolactin binding to Leydig cells in prepubertal and pubertal rats. Horm. Metab. Res., 31(11):583-6, 1999.
Sujatha, S. \& Shalin, J. J. Complementary therapeutic potential: A focus on polyherbal products for hyperglycemia. Asian J. Sci. Res., 5(1):113, 2012.

Tocmo, R.; Liang, D.; Lin, Y. \& Huang, D. Chemical and biochemical mechanisms underlying the cardioprotective roles of dietary organopolysulfides. Front. Nutr., 2:1, 2015.

Weibel, E. R. \& Paumgartner, D. Integrated stereological and biochemical studies on hepatocytic membranes. II. Correction of section thickness effect on volume and surface density estimates. J. Cell Biol., 77(2):58497, 1978.

Yadav, Y. C.; Srivastav, D. N.; Seth, A. K.; Saini, V.; Balaraman, R. \& Ghelani, T. K. In vivo antioxidant potential of Lepidium sativum L. seeds in albino rats using cisplatin induced nephrotoxicity. Int. J. Phytomed., 2(3):292-8, 2010.

\author{
Corresponding author: \\ Dr. Hossein Nikzad \\ Gametogenesis Research Center \\ Kashan University of Medical Sciences \\ Kashan \\ IRAN
}

\section{E-mail: hnikzad@yahoo.com nikzad_h@kaums.ac.ir}

Received:01-01-2017

Accepted:06-04-2017 